\title{
Post-M\&A Operating Performance of Indian Acquiring Firms: A Du Pont Analysis
}

\author{
Neelam Rani ${ }^{1}$, Surendra S. Yadav ${ }^{1} \&$ P. K. Jain ${ }^{1}$ \\ ${ }^{1}$ Department of Management Studies, Indian Institute of Technology Delhi, New Delhi, India \\ Correspondence: Neelam Rani, Department of Management Studies, Indian Institute of Technology Delhi, \\ Vishwakarma Bhawan, Shaheed Jit Singh Marg, Hauz Khas, New Delhi, 110016, India. E-mail: \\ neelam.iitd@gmail.com
}

$\begin{array}{ll}\text { Received: May 23, } 2013 & \text { Accepted: June 18, } 2013 \quad \text { Online Published: July 26, } 2013 \\ \text { doi:10.5539/ijef.v5n8p65 } & \text { URL: http://dx.doi.org/10.5539/ijef.v5n8p65 }\end{array}$

\begin{abstract}
This paper investigates the impact of mergers and acquisitions (M\&A) on corporate performance. It compares performance of the corporates involved in M\&A before and after M\&A. The results pertaining to operating cash flow ratios show that there is an improvement in performance of the acquiring firms in the post-M\&A period. The analysis in terms of Du Pont shows improvement in the long-term operating profit margin of the acquiring firms. This indicates that the acquiring firms earn higher profits per unit net sales after M\&A. The higher cash flows are generated primarily due to the better operating margins.
\end{abstract}

Keywords: merger \& acquisition, operating performance, synergy, assets turnover

\section{Introduction}

Mergers and acquisitions (M\&A) as growth strategy have received attention from developed as well as emerging economies. Globalization and liberalization have led firms from emerging markets like India to become more aggressive and opt for M\&A to fight the competitive battle.

M\&A are one of the mechanisms by which firms gain access to new resources; via resource redeployment, they increase revenues and reduce cost. But, does the financial performance of the acquiring firm (in long-term) really improve following mergers and acquisitions? The present paper intends to measure the impact of M\&A on long-term performance of the acquiring firms. It investigates profitability as well as operating performance. This paper addresses the major question related to the long-term performance of the acquiring firm. This study uses long-term financial data before and after merger and acquisition to determine firm operating performance of acquiring firms. A sufficiently long period is required to understand and analyze the impact of a merger and acquisition since efficiency improves over a long time horizon. Hence, operating performance of Indian acquirers for ten years period-five years prior to and subsequent to the merger and acquisition has been observed.

For better exposition, the remainder of the paper has been organized in four sections. Section 2 reviews select relevant existing empirical works on the subject. Section 3 delineates sources of data and research methodology; it also describes the variables and empirical method used in analysis of pre-merger and post-merger corporate performance; section 4 documents the empirical findings. Finally, section 5 provides summary and discusses concluding observations and implications.

\section{Literature Review}

There has been an ongoing debate on short-term as well as long-term performance of M\&A. Voluminous literature exists to support the debate on whether mergers create value or are wealth reducing events. Empirical work on the issue has adopted two major approaches; share price analysis and accounting measure analysis to investigate the issues related to mergers profitability. Extant literature based on share price analysis use event studies to investigate the short-term returns to shareholders during the period surrounding announcement of merger deals. These studies have not been able to investigate the long-term economic gains of mergers. Studies analyzing accounting measures examined the financial results reported by corporate to assess post-merger performance.

These studies have focused on the comparative analysis of accounting statements of the acquirers before and after M\&A to observe how they affect the financial performance. The present section briefly describes the survey 
of relevant studies in this context.

Healy et al. (1992) investigated the 50 largest US acquisitions during the period January 1979 to June 1984. They have analyzed the post-merger operating performance of the combined firm using industry median as benchmark. They have observed that operating performance improves significantly after merger. The study has been criticized for using industry median firms as benchmark.

Switzer (1996) has extended the Healy et al. (1992) study to analyse the operating performance of a larger sample of 327 merged firms during a larger period 1967-1987 in US. She has criticized Healy et al. (1992) for analyzing the large 50 mergers and dealing with the time period categorized as "merger mania". She has also documented the improved post-merger operating efficiency for a substantially large sample and involving larger period. She has also observed positive association between abnormal return surrounding the announcement and the long-term performance of the merged firms. Manson et al. (2000) further investigated a sample of 44 takeovers in UK during 1985-1987 by using the similar cash flow variables and methodology used by Healy et al. (1992). They have observed significant operating as well as non-operating gains resulting from takeovers in UK.

Ramaswamy and Waegelein (2003) have examined the financial performance of the target and acquiring firms over 5 years post-merger period using a sample of 162 US firms during the period 1975-1990. The study has also followed Healy et al. (1992) measure of performance (industry adjusted cash flow returns on market value of assets). They have also observed a significant improvement in post-merger financial performance. Parrino and Harris (1999) examined operating performance of 197 mergers during 1982-1987. They observed a significant increase of 2.1 per cent in acquirers operating cash flow return post-merger. The study defined the cash flow return as operating cash flow divided by market value of assets. Rahman and Limmack (2004) have investigated operating performance of industry-matched control sample of 94 listed and 113 private Malaysian companies during 1988-1992. Their findings reveal that post-merger operating performance improved to the extent of 3.75 per cent per year.

Ravenscraft and Scherer (1989) examined financial performance of target firms during 1957-1977 in US. They have investigated 2732 lines of business by US manufacturing companies. They have observed that mergers have substantial negative impact on the post-merger profitability. They have concluded that mergers destroy value in respect of profitability.

Ghosh (2001) has investigated performance of 315 US mergers completed during the period 1981-1995. He has used control firms as benchmark instead industry median firms unlike Healy et al. (1992). He has selected the control firms matched on performance and total asset size from pre-merger years to use as benchmark. The study also replicated the methodology used by Healy et al. (1992). He has observed that operating performance does not improve if the firms matched on performance and size is used as benchmark.

Sharma and Ho (2002) also replicated the methodology used by Healy et al. (1992). They have used a sample of 36 manufacturing firms during 1986-1991 in Australia to investigate the improvement in post-acquisition operating efficiency. They have used matched sample based on assets size and industry to control for industry and economic factors. They have not observed significant improvement in post- acquisition operating performance.

Yeh and Hoshino (2000) investigated the impact of mergers and acquisitions on both the acquiring firms' stock prices and financial performance by using a sample of 20 Taiwanese corporations during 1987-1992. They have examined accounting measures of profitability, financial health and growth of the acquirers. They have observed that the stock market reacts positively to the announcements of mergers and acquisitions, but profitability shows a downward change from pre-merger to post-merger periods. Unlike previous studies, they have not observed any significant correlation between stock returns and the change in accounting performance.

Gugler et al. (2003) have analyzed the effects of mergers around the world by using a large panel of data over the past 15 years. They have examined effects of the mergers by comparing the performance of profitability and sales of the merging firms with control groups of non-merging firms. Their findings show that mergers result in significant increases in profits but reduce the sales of the merging firms. They have observed similar post-merger patterns across countries. They have not traced differences between mergers in the manufacturing and the service sectors, and between domestic and cross-border mergers. The study also reports that conglomerate mergers decrease sales more than horizontal mergers.

Ghosh and Jain (2000) investigated whether merging firms increase their financial leverage after mergers on the basis of a sample of 239 mergers during 1978 and 1987 in US. Their results show that the mean financial leverage increases by 17 per cent compared to the pre-merger financial leverage of the combined firms. 
Studies of mergers in India are very few. Moreover, these empirical investigations have focused on comparing pre-merger and post-merger performance on case to case basis.

Pawaskar (2001) has conducted an investigation in India by using the methodology developed by Cosh et al. (1998) and Mueller (1986) to analyze the pre-and post-merger operating performance of acquiring firm. Pawaskar has also identified the sources of merger induced changes by using a sample of 36 mergers during 1992-1995. He has observed that corporate performance has not improved significantly post-merger. The study has certain limitations due to control group used and the small size of the sample. Ramakrishnan (2008) studied a sample of 87 domestic mergers of Indian companies during the period 1996-2002 to study the long-term performance of merged companies. The study reports improvement in the operating performance accounting measures.

In an empirical survey of 152 companies, Rani et al. (2010) have observed that the primary motive of mergers in India during 2003-2008 has been to take advantage of synergies. Operating economies, increased market share and financial economies have been indicated in order of importance as the desired synergies to be gained through corporate merger in India.

In a review paper, Bruner (2002) reported that out of fifteen studies he reviewed on acquiring firms' financial performance post-merger and acquisition, four studies reported negative performance post-acquisition and three studies reported significantly positive performance, eight studies reported non-significant change.

Mueller (1980) noticed no consistent pattern of either improved or deteriorated profitability in review of collection of studies across seven nations (Belgium, German, France, Netherlands, Sweden, UK and US).

It is evident from the findings of various studies that empirical research on post-merger long-term performance throughout world has not converged to a conclusion whether mergers are wealth enhancing or value destroying. In the present study, an attempt has been made to examine post-merger performance by utilizing operating measures. The study focuses on analysis of changes in operating performance. The change is examined by comparing operating performance before and after merger. The study contributes to the existing literature by comparing operating performance of acquirers before and after M\&A using operating cash flow ratios for a substantially large sample.

\section{Methodology, Data and Scope of the Study}

The methodology aims at examining whether the financial performance of the acquiring firm really improves following mergers and acquisitions. The secondary sources of data have been used for the present study. The major sources are Capitaline, Prowess database of Center for Monitoring Indian Economy (CMIE), websites of National Stock Exchange (NSE) and Bombay Stock Exchange (BSE). The study is performed on the database that includes the ten year data of the acquiring company.

The sample for this study consists of acquiring companies involved in merger and acquisitions during January 2003 to December 2008. The initial announcements of merger and acquisition by public-listed Indian acquirer companies have been identified from Centre for Monitoring Indian Economy (CMIE) database Prowess. Mergers and acquisitions made by financial companies, withdrawn and denial of news of deal subsequently, mergers not approved by Government, formation and exit from joint ventures, acquisitions of business, assets, divisions and brands, acquisitions of less than controlling stake have been excluded from the sample. Information regarding completion of merger has been obtained from websites of BSE, NSE and annual reports of the companies. These exclusions left us with a sample of 383 mergers and acquisitions. The study is limited to performance of acquiring firms only.

The final sample consists of 383 mergers and acquisitions. Table 1 describes the distribution of sample across years. It is evident from the Table that the maximum 38 per cent of mergers and acquisitions took place in year 2007. Extreme values have been excluded from the data to do away with the influence of outliers. After analyzing data for outliers, the values beyond three standard deviations have been dropped from the analysis. Only those firms have been retained in analysis for which data is available in pairs of prior and after one year of M\&A $(-1,1)$, one year before and two year mean after M\&A $(-1,2)$, one year before and three year mean after M\&A $(-1,3)$, one year before and four year mean after $\operatorname{M\& A}(-1,4)$, one year before and five year mean after M\&A $(-1,5)$, two years of M\&A (2, 2), three years of M\&A $(-3,3)$, four years of M\&A $(-4,4)$ and five years of M\&A $(-5,5)$.

Due to these inconsistency, the number of firms utilized for long-term analysis of financial performance (ratio analysis) varied: 305 firms for one year before and after M\&A, 295 firms for one year before and two year mean after M\&A (-1,2), 260 firms for one year before and three year mean after M\&A (-1, 3), 230 firms for one year 
before and four year mean after M\&A (-1, 4), 133 firms for one year before and five year mean after M\&A (-1, $5)$, the mean of two years before and after M\&A $(-2,2)$ of 285 firms, the mean of three years before and after M\&A $(-3,3)$ of 259 firms, the mean of four years before and after M\&A $(-4,4)$ of 214 firms, the mean of five years before and after M\&A(-5,5) of 124 firms have been analyzed. The final sample consists of 63.3 percent firms in manufacturing sector, 31.15 firms in services sector, 4.92 per cent in construction and real estate, 1.3 per cent in mining, electricity and diversified sector.

Table 1. Distribution of sample across years, 2003-2008

\begin{tabular}{ccc}
\hline Year & Number of merger and acquisition studied & Number of merger and acquisition analyzed \\
\hline 2003 & $23(6 \%)$ & $19(6.2 \%)$ \\
2004 & $21(5.4 \%)$ & $17(5.6 \%)$ \\
2005 & $37(9.6 \%)$ & $30(9.8 \%)$ \\
2006 & $87(22.7 \%)$ & $77(25.2 \%)$ \\
2007 & $144(37.6 \%)$ & $112(36.7 \%)$ \\
2008 & $71(18.4 \%)$ & $50(16.4 \%)$ \\
Total & $383(100 \%)$ & $305(100 \%)$ \\
\hline
\end{tabular}

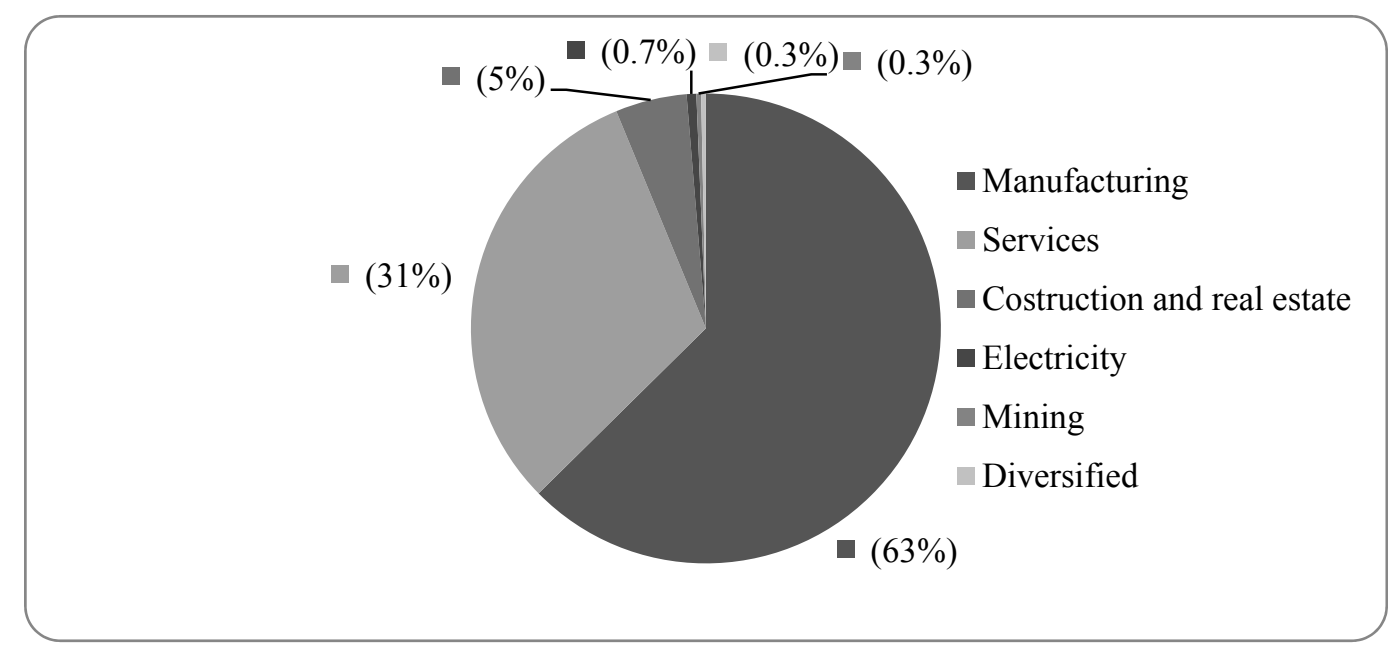

Figure 1. Sector-wise distribution of sample

The present work uses the long-term financial data of five years prior to and subsequent to M\&A to investigate the long-term performance. The operating performance of the companies for ten years, five years before and five years after M\&A has been reported. Pre-merger (period -5 to -1 ) and post-merger (period 1 to 5) performance has been calculated for the acquiring company. The year of merger and acquisition (Year 0) has been excluded from the analysis as its inclusion may cause distortions due to change in financial reporting caused because of adjustments in accounting. In order to provide a holistic view of the long-term performance of mergers and acquisitions, operating cash flow ratios have been investigated in the study.

The study measures and compares the pre-and post merger and acquisition financial performance of acquiring companies in terms of operating cash flows. The improvement in profitability in post-M\&A period can arise from various sources such as better operating margins, higher assets productivity, reduced costs or enhanced market power etc. Cash flow measures capture the actual economic gains from assets. Pre-tax operating cash flows scaled by sales as well as assets are used to measure the change in performance measures. 


$$
O C F R_{A}=\frac{\text { Profit before interest and taxes-nonoperating income }+ \text { depreciati on }+ \text { amortisati on }}{\text { Average of }(\text { total assets-preliminer yexpenses-fictitious assets-miscell expenses }}
$$

Operating cash flow ratio based on sales $\mathrm{OCFR}_{\mathrm{S}}$ has also been calculated:

$$
O C F R_{S}=\frac{\text { Profit before interest and taxes-nonoperating income }+ \text { depreciati on }+ \text { amortisati on }}{\text { Net sales }}
$$

Total assets turnover indicates the efficiency with which the firm uses its assets to generate sales. This measure is probably of the greatest interest to management because it indicates whether firm's operations have been financially efficient (Gitman, 2009, p. 82) Accordingly, total assets turnover ratio (TATR) has been computed by dividing net sales to average total assets. Total assets have been used net of preliminary expenses, fictitious assets and miscellaneous expenses.

Total assets turnover ratio (TATR) has been computed by dividing net sales to average total assets. Total assets have been used net of preliminary expenses, fictitious assets and miscellaneous expenses.

$$
T A T R=\frac{\text { Net sales }}{\text { Average of (total assets-preliminer yexpenses-fictitious assets-miscell expenses }}
$$

To determine the significant difference over pre-and post-merger and acquisition, two-sample paired t- test has been conducted for each measure used in the study. The null hypothesis for each test is that the mean level for the post-merger and acquisition period is not significantly different from the mean from pre-merger and acquisition period. A positive t-value indicates a higher mean value for post-merger and acquisition period and vice-versa. The empirical evidence presented in the paper validates the hypothesis that Indian acquirers have performed better after M\&A, compared to their performance in pre-M\&A period. The findings indicate that M\&A seem to have been beneficial for the acquiring companies in the long-run with regard to their operating performance. The results suggest that profitability of acquiring firms has improved during post-M\&A phase. Mergers and acquisitions have resulted to better and improved performance.

\section{Empirical Results}

The objective of the present paper is to compare the operating performance of acquirers before and after M\&A in terms of sales as well as assets. It is hypothesized that acquirers have posted better post-M\&A financial performance vis-à-vis pre-M\&A performance.

The paired samples t-test for comparison of means provides a test-statistics of $2.72(\mathrm{p}=0.007<0.01)$ for OCFRS for one year difference (Table 2). The mean difference is positive for all the pairs. These results validate the hypothesis that M\&A in India have resulted in improved long-term operating performance. The paired test is also carried out for operating cash flow ratio based on assets. OCFR based on assets reveal that in comparison to one year before the acquirers are able to generate higher operating cash flows five years post-M\&A $(-1,+5)$. The performance of acquiring firms appear to have improved significantly in fifth year after M\&A as indicated by t-statistics of $2.45(\mathrm{p}=0.02<0.05)$. The improvement seems to be higher as the years progress subsequent to the event of M\&A. The change in post-M\&A performance in each of the four and five year are not significant.

\subsection{Analysis of Sources of Performance}

The improvement in the period, following M\&A can arise from various sources such as better operating margins, greater assets productivity, lower labor costs or higher volume or higher sales etc. In order to ascertain the sources of the better long-term returns subsequent to M\&A, the measure of operating performance has been decomposed into its constituents in terms of Du Pont analysis. Du Pont analysis indicates that the profitability is improved either by improving profit margin per rupees of sales or by generating more sales revenue per rupee of investment. The operating cash flow ratio $\left(\mathrm{OCFR}_{\mathrm{A}}\right)$, based on assets, can be decomposed into operating cash flow based on sales and total assets turnover ratio. 
Table 2. Paired sample t-test of operating cash flow ratios before and after M\&A

\begin{tabular}{|c|c|c|c|c|c|c|c|}
\hline $\begin{array}{l}\text { Paired sample } \\
\text { (before, after) }\end{array}$ & $\begin{array}{l}\text { Mean ratio } \\
\text { after-M\&A }\end{array}$ & $\begin{array}{c}\text { Mean ratio } \\
\text { before -M\&A }\end{array}$ & $\begin{array}{c}\text { Mean } \\
\text { difference }\end{array}$ & $\begin{array}{l}\text { Positive: } \\
\text { Negative }\end{array}$ & T-Value & $\begin{array}{l}\text { Degree of } \\
\text { freedom }\end{array}$ & Significance \\
\hline \multicolumn{8}{|c|}{ Operating cash flow ratio based on sales $\left(\mathrm{OCFR}_{\mathrm{S}}\right)$} \\
\hline$(-1,+1)$ & 20.1 & 18.9 & 1.2 & $190: 115$ & $2.72 * *$ & 304 & 0.007 \\
\hline$(-1,+2)$ & 25.3 & 19.4 & 5.9 & $167: 128$ & 1.25 & 294 & 0.21 \\
\hline$(-1,+3)$ & 16.5 & 14.8 & 1.7 & $150: 112$ & 0.027 & 261 & 0.93 \\
\hline$(-1,+4)$ & 19.6 & 15.1 & 4.5 & 140:90 & 1.41 & 229 & 0.15 \\
\hline$(-1,+5)$ & 18.1 & 17.1 & 1 & $85: 40$ & 1.14 & 132 & 0.26 \\
\hline$(-2,+2)$ & 19.2 & 18.7 & 0.5 & 170:115 & 1.62 & 284 & 0.11 \\
\hline$(-3,+3)$ & 19.6 & 16.1 & 3.5 & 160:198 & 1.25 & 258 & 0.21 \\
\hline$(-4,+4)$ & 19.7 & 19.1 & 0.6 & 134:80 & 0.237 & 213 & 0.81 \\
\hline$(-5,+5)$ & 17.8 & 16.6 & 1.2 & $71: 53$ & 0.971 & 123 & 0.33 \\
\hline \multicolumn{8}{|c|}{ Operating cash flow ratio based on assets $\left(\mathrm{OCFR}_{\mathrm{A}}\right)$} \\
\hline$(-1,+1)$ & 15.7 & 15.5 & 0.2 & $162: 143$ & 0.85 & 304 & 0.4 \\
\hline$(-1,+2)$ & 14.9 & 14.3 & 0.6 & $127: 168$ & 1.01 & 294 & 0.28 \\
\hline$(-1,+3)$ & 14 & 13.7 & 0.3 & $139: 123$ & 0.6 & 261 & 0.56 \\
\hline$(-1,+4)$ & 14.1 & 13.6 & 0.5 & $124: 106$ & 0.883 & 229 & 0.38 \\
\hline$(-1,+5)$ & 15.3 & 14.2 & 1.1 & $67: 66$ & $2.45^{*}$ & 132 & 0.02 \\
\hline$(-2,+2)$ & 14.5 & 14.8 & -0.3 & $128: 157$ & -0.605 & 284 & 0.55 \\
\hline$(-3,+3)$ & 14.2 & 14.4 & -0.2 & $126: 132$ & -0.42 & 258 & 0.68 \\
\hline$(-4,+4)$ & 13.9 & 13.8 & 0.1 & 109:104 & 0.149 & 213 & 0.88 \\
\hline$(-5,+5)$ & 14 & 13.9 & 0.1 & $65: 58$ & 0.188 & 123 & 0.85 \\
\hline
\end{tabular}

$*$ and $* *$ Denote significance at 5 per cent and 1 per cent, respectively.

The operating cash flow ratio based on assets $\left(\mathrm{OCFR}_{\mathrm{A}}\right)$ calculated as operating cash flow (OCF) divided by average total assets equation (4). $\mathrm{OCFR}_{\mathrm{A}}$ may be decomposed into the operating cash flow based on sales $\left(\mathrm{OCFR}_{\mathrm{s}}\right)$ equation (5) and the total assets turnover ratio as per equation (6):

$$
O C F R_{A}=\frac{\text { Profit before interest and taxes-nonoperating income }+ \text { depreciati on+amortisati on }}{\text { Average total assets }}
$$

Or

$$
O C F R_{A}=\frac{\text { Profit before interest and taxes-nonoperating income }+ \text { depreciati on }+ \text { amortisati on }}{\text { Net sales }} \times \frac{\text { Net sales }}{\text { Average total assets }}
$$

Where

\section{Profit before interest and taxes-nonoperating income +depreciati on+amortisati on}

$$
\text { Net sales }
$$$$
=\text { Operating cash flow ratio based on sales }\left(O C F R_{S}\right)
$$

And

$$
\frac{\text { Net sales }}{\text { Average total assets }}=\text { total assets turnover ratio (TATR) }
$$

In Du Pont terms:

$$
O C F R_{A}=O C F R_{S} \times T A T R
$$


Table 3. Paired sample T-test of constituent ratios in terms of Du Pont before and after M\&A

\begin{tabular}{|c|c|c|c|c|c|c|c|}
\hline $\begin{array}{l}\text { Paired sample } \\
\text { (before, after) }\end{array}$ & $\begin{array}{l}\text { Mean ratio } \\
\text { after-M\&A }\end{array}$ & $\begin{array}{c}\text { Mean ratio } \\
\text { before-M\&A }\end{array}$ & $\begin{array}{c}\text { Mean } \\
\text { difference }\end{array}$ & $\begin{array}{l}\text { Positive: } \\
\text { Negative }\end{array}$ & T-Value & $\begin{array}{l}\text { Degree of } \\
\text { freedom }\end{array}$ & Significance \\
\hline \multicolumn{8}{|c|}{ Operating cash flow ratio based on sales $\left(\mathrm{OCFR}_{\mathrm{S}}\right)$} \\
\hline$(-1,+1)$ & 20.1 & 18.9 & 1.2 & 190:115 & $2.72 * *$ & 304 & 0.007 \\
\hline$(-1,+2)$ & 25.3 & 19.4 & 5.9 & $167: 128$ & 1.25 & 294 & 0.21 \\
\hline$(-1,+3)$ & 16.5 & 14.8 & 1.7 & $150: 112$ & 0.027 & 261 & 0.93 \\
\hline$(-1,+4)$ & 19.6 & 15.1 & 4.5 & $140: 90$ & 1.41 & 229 & 0.15 \\
\hline$(-1,+5)$ & 18.1 & 17.1 & 1 & $85: 40$ & 1.14 & 132 & 0.26 \\
\hline$(-2,+2)$ & 19.2 & 18.7 & 0.5 & 170:115 & 1.62 & 284 & 0.11 \\
\hline$(-3,+3)$ & 19.6 & 16.1 & 3.5 & $160: 198$ & 1.25 & 258 & 0.21 \\
\hline$(-4,+4)$ & 19.7 & 19.1 & 0.6 & $134: 80$ & 0.237 & 213 & 0.81 \\
\hline$(-5,+5)$ & 17.8 & 16.6 & 1.2 & $71: 53$ & 0.971 & 123 & 0.33 \\
\hline \multicolumn{8}{|c|}{ Operating cash flow ratio based on assets $\left(\mathrm{OCFR}_{\mathrm{A}}\right)$} \\
\hline$(-1,+1)$ & 15.7 & 15.5 & 0.2 & $162: 143$ & 0.85 & 304 & 0.4 \\
\hline$(-1,+2)$ & 14.9 & 14.3 & 0.6 & $127: 168$ & 1.01 & 294 & 0.28 \\
\hline$(-1,+3)$ & 14 & 13.7 & 0.3 & $139: 123$ & 0.6 & 261 & 0.56 \\
\hline$(-1,+4)$ & 14.1 & 13.6 & 0.5 & $124: 106$ & 0.883 & 229 & 0.38 \\
\hline$(-1,+5)$ & 15.3 & 14.2 & 1.1 & $67: 66$ & $2.45 *$ & 132 & 0.02 \\
\hline$(-2,+2)$ & 14.5 & 14.8 & -0.3 & $128: 157$ & -0.605 & 284 & 0.55 \\
\hline$(-3,+3)$ & 14.2 & 14.4 & -0.2 & $126: 132$ & -0.42 & 258 & 0.68 \\
\hline$(-4,+4)$ & 13.9 & 13.8 & 0.1 & 109:104 & 0.149 & 213 & 0.88 \\
\hline$(-5,+5)$ & 14 & 13.9 & 0.1 & $65: 58$ & 0.188 & 123 & 0.85 \\
\hline \multicolumn{8}{|c|}{ Total assets turnover ratio } \\
\hline$(-1,+1)$ & 0.94 & 0.96 & -0.02 & $141: 164$ & -1.06 & 304 & 0.29 \\
\hline$(-1,+2)$ & 0.92 & 0.98 & -0.06 & $173: 122$ & $-2.63 * *$ & 294 & 0.009 \\
\hline$(-1,+3)$ & 0.89 & 0.96 & -0.07 & $168: 94$ & $-2.86 * *$ & 261 & 0.005 \\
\hline$(-1,+4)$ & 0.89 & 0.95 & -0.56 & $101: 129$ & $-2.13 *$ & 229 & 0.03 \\
\hline$(-1,+5)$ & 0.96 & 1.08 & -0.13 & $51: 81$ & $-2.78 * *$ & 132 & 0.006 \\
\hline$(-2,+2)$ & 0.92 & 0.97 & -0.05 & 114:171 & -1.86 & 284 & 0.07 \\
\hline$(-3,+3)$ & 0.90 & 0.94 & -0.04 & $105: 154$ & -1.76 & 258 & 0.079 \\
\hline$(-4,+4)$ & 0.89 & 0.91 & -0.02 & $92: 122$ & -.941 & 213 & 0.348 \\
\hline$(-5,+5)$ & 0.93 & 0.96 & -0.03 & $59: 65$ & -1.09 & 123 & 0.066 \\
\hline
\end{tabular}

$*$ and ** Denote significance at 5 per cent and 1 per cent, respectively.

The operating cash flow based on sales indicates the operating cash flow obtained through each unit of sales. Total assets turnover depicts the efficiency with which the firm uses its assets to generate sales. The relevant data contained in Table 3 shows that the operating profit margin based on sales have improved post-M\&A. As we have divided the operating profit of the acquirer with the net sales of the acquirer, the positive and significant changes in operating cash flow after M\&A reveals that the acquirer seems to have produced higher operating profit per unit net sales after M\&A. The better operating margin appears to be due to the lower of costs as a result of economies of scale. Negative T-values identified by paired sample t-test on expense ratio also corroborates this finding. Further, the evidence of increase in the operating profit margin based also supports these results.

The assets utilization efficiency to produce higher sales does not appear to have improved as revealed by total assets turnover ratio during post-M\&A period. It cannot be inferred that total assets turnover of acquiring firms after the M\&A is significantly different from their total assets turnover before M\&A. On the basis of these results, it may not be concluded that M\&A have led to higher total assets turnover. These results depict that it is unlikely that acquirer firms have produced higher incremental sales by improving their assets utilization efficiency. 


\section{Concluding Observations}

The present paper aims at analyzing the operating performance of corporates involved in M\&A in India. The major hypothesis is that acquiring firms have improved post-M\&A operating performance. The empirical evidence validates the hypothesis that Indian acquirers have performed better after M\&A, compared to their performance in pre-M\&A period.

The study indicates that M\&A appear to have been beneficial for the acquiring companies in the long-run with regard to their operating performance. The findings suggest that profitability of acquiring firms has improved during post-M\&A phase. Mergers and acquisitions have resulted to better and improved performance.

However, mergers and acquisitions have not resulted improvement in assets turnover ratios, as initially there might not be increase in sales and any consequently, further improvement in combined capacity utilization may not be possible. Therefore, assets turnover ratio improves slowly. It appears that global recessionary conditions in the year 2008 resulted in low assets turnovers of acquiring firms.

Further, the disaggregated analysis of the measure of operating cash flows into its two constituents in terms of $\mathrm{Du}$ Pont (operating cash flow ratio based on sales and total assets turnover based on sales) reveal that the long-term operating cash flow ratio based on sales of the acquiring firms have improved. The Du Pont analysis in terms of its components provides insights into sources of the economic performance. The analysis indicates that net sales have resulted higher per unit profit of the acquiring firms after the M\&A.

The better margins have led to higher operating cash flows. This may be due to the reduced cost, economies of scale and operating synergies obtained by the acquired firms' larger size after M\&A. Further, the evidence of significant increase in the operating cash flow also supports these results.

However, assets turnover of the acquiring firms does not seem to have improved, after M\&A (also revealed by paired samples t-test); assets invested have not generated higher sales after M\&A. In operational terms, the efficiency/utilization of assets does not get manifested in generating higher net sales after M\&A. In operational terms, the efficiency in assets utilization does not increase and result into higher net sales after M\&A. That may be, partly, due to recessionary conditions in global economy after 2008. The implications of the present paper for acquiring firms is that economic benefits may be realized due to cost synergies and economies of scale (reduced cost leading to better profit margins) when it is difficult to realize revenue synergies in recessionary conditions.

On the basis of Do Pont analysis, it may be concluded that acquiring firms in India appear to have performed better after M\&A in comparison to their performance before M\&A, primarily due to reduced cost, economies of scale and operational synergies.

\section{References}

Bruner, R. F. (2002). Does M\&A pay? A survey of evidence for the decision maker. Journal of Applied Finance, 12 (Spring/Summer), 48-68.

Chatterjee, R., \& Meeks, G. (1996). The financial effects of takeover: Accounting rates of return and accounting regulation. Journal of Business Finance and Accounting, 23(5/6), 851-868. http://dx.doi.org/10.1111/j.1468-5957.1996.tb01155.x

Cosh, A., Hughes, A., Lee, K., \& Singh, A. (1998). Takeovers, institutional investment and the persistence of profits. In Begg, I., \& Henry, B. (Eds.), Applied Economics and Public Policy, Department of Applied Economics Occasional (pp. 107-144). Cambridge: Cambridge University Press. Retrieved from http://www.cbr.cam.ac.uk/pdf/wp030.pdf

Ghosh, A. (2001). Does operating performance really improve following corporate acquisition? Journal of Corporate Finance, 7(2), 151-178. http://dx.doi.org/10.1016/S0929-1199(01)00018-9

Ghosh, A., \& Jain, P. C. (2000). Financial leverage changes associated with corporate mergers. Journal of Corporate Finance, 6(4), 377-402. http://dx.doi.org/10.1016/S0929-1199(00)00007-9

Gitman, L. J. (2009), Principles of Managerial Finance (XI Ed). New York: Pearsons.

Gugler, K., Mueller, D. C., Yurtoglu, B., \& Zulehner, C. (2003). The effects of mergers: An international comparison. International Journal of Industrial Organization, 21(5), 625-653. http://dx.doi.org/10.1016/S0167-7187(02)00107-8

Healy, P. M., Palepu, K. G., \& Ruback, R. S. (1992). Does corporate performance improve after mergers? Journal of Financial Economics, 31(2), 135-175. http://dx.doi.org/10.1016/0304-405X(92)90002-F

Jain, P. K., \& Yadav, S. S. (2000). Financial management practices in select private corporate enterprises. New 
Delhi: Hindustan Publishing Company.

Manson, S., Powell, R., Stark, A. W., \& Thomas, H. M., (2000). Identifying the sources of gains from takeovers. Accounting Forum, 24(4), 319-343. http://dx.doi.org/10.1111/1467-6303.00044

Meeks, G. (1977). Disappointing marriage: A study of the gains from mergers. Cambridge, MA: Cambridge University Press.

Mueller, D. (1980). The determinants and effects of mergers: An international comparison. Cambridge, MA: Oelgeschlager, Gunn and Hain.

Mueller, D. C. (1986). Profits in the long run. New York and Sydney: Cambridge University Press. http://dx.doi.org/10.1017/CBO9780511664731

Parrino, J. D., \& Harris, R. S. (1999). Takeovers management and replacements, and post-acquisition operating performance: Some evidence from 1980s. Journal of Applied Corporate Finance, 11(4), 88-97. http://dx.doi.org/10.1111/j.1745-6622.1999.tb00518.x

Parrino, J. D., \& Harris, R. S. (2001). Business linkages and post-merger operating performance. Working Paper, Darden Graduate School of Business, University of Virginia, Charlottesville.

Pawaskar, V. (2001). Effect of mergers on corporate performance in India. Vikalpa, 26(1), 19-32.

Rahman, R. A., \& Limmack, R. J. (2004). Corporate acquisitions and the operating performance of Malaysian companies. Journal of Business Finance and Accounting, 31(3/4), 359-400. http://dx.doi.org/10.1111/j.0306-686X.2004.00543.x

Ramakrishnan, K. (2008). Long-term post-merger performance of firms in India. Vikalpa, 33(2), 47-63.

Ramaswamy, K. P., \& Waegelein, J. F. (2003). Firm financial performance following mergers. Review of Quantitative Finance and Accounting, 20(2), 115-126. http://dx.doi.org/10.1023/A:1023089924640

Rani, N., Yadav, S. S., \& Jain, P. K. (2010). Corporate merger practices in India: An empirical study. In proceedings of Tenth Global Conference on Flexible Systems Management GLOGIFT10, (pp. 26-27) July, Graduate School of System Design and Management Collaboration Complex, Hiyoshi Campus, Keio University, Japan. Retrieved from http://ssrn.com/abstract=2043698

Ravenscraft, D. J., \& Scherer, F. M. (1989). The profitability of mergers. International Journal of Industrial Organization, 7(1), 101-116. http://dx.doi.org/10.1016/0167-7187(89)90048-9

Sharma, D. S., \& Ho, J. (2002). The impact of acquisitions on operating performance: Some Australian evidence. Journal of Business Finance and Accounting, 29(1\&2), 155-200. http://dx.doi.org/10.1111/1468-5957.00428

Switzer, J. A. (1996). Evidence on real gains in corporate acquisitions. Journal of Economics and Business, 48(5), 443-460. http://dx.doi.org/10.1016/S0148-6195(96)00033-1

Yeh, T. M., \& Hoshino, Y. (2000). The effects of mergers and acquisitions on Taiwanese corporations. Review of Pacific Basin Financial Markets and Policies, 3(2), 183-199. http://dx.doi.org/10.1142/S0219091500000108

\section{Copyrights}

Copyright for this article is retained by the author(s), with first publication rights granted to the journal.

This is an open-access article distributed under the terms and conditions of the Creative Commons Attribution license (http://creativecommons.org/licenses/by/3.0/). 